\title{
Identification of sorghum hybrids for silage production in the semiarid (BSh) region of northeastern Brazil
}

\section{Identificação de híbridos de sorgo para produção de silagem na região semiárida (BSh) no Nordeste do Brasil}

\author{
Romilda Rodrigues do Nascimento ${ }^{1 *}$; Ricardo Loiola Edvan²; José Morais Pereira \\ Filho $^{3}$; José Avelino Santos Rodrigues ${ }^{4}$; Marcos Jácome de Araújo ${ }^{2}$; Alex Lopes da \\ Silva $^{5} ;$ Keuven dos Santos Nascimento ${ }^{6}$; Caio Oliveira Santos ${ }^{7}$
}

\section{Highlights:}

Sorghum has great potential for use in semiarid regions.

Hybrid 947252 had the highest stem mass yield.

Hybrids SF 15, 947072, and 947030 had the highest values of crude protein in silage.

\begin{abstract}
The objective of this study was to identify the hybrids of sorghum most suitable for the production of silage in the semiarid regions of northeastern Brazil. Twenty-three hybrids were evaluated in a randomized block design with three replicates. The dry mass yield; dry mass of leaf, stem, panicle, grains, and senescent matter; and chemical composition of the plant were evaluated. The $\mathrm{pH}$, ammoniacal nitrogen $\left(\mathrm{N}-\mathrm{NH}_{3}\right)$, and chemical composition of the silage were also assessed. The hybrids 947252 , FEPAGRO 18, 12F042226, and SF 11 performed best in terms of morphological characteristics, with the highest mass of leaves and grains. The hybrid FEPAGRO 19 had the highest dry matter value (443.3 $\left.\pm 17.0 \mathrm{~g} \mathrm{~kg}^{-1}\right)$, whereas the hybrid $12 \mathrm{~F} 042496$ had the lowest value $\left(271.3 \pm 17.0 \mathrm{~g} \mathrm{~kg}^{-1}\right)$. The dry matter (DM) content of the other hybrids was within the recommended values for silage production (280 to $400 \mathrm{~g} \mathrm{~kg}^{-1}$ ). High levels of crude protein were observed in the grouped hybrids 12F042496, 947254, and 12F042422. The hybrid 12F042496 had the highest neutral detergent fiber content. The hybrids 9929036, 9929030, 9929012, 947254, 947072, PROG 134 IPA, 12F042226, 12F042422, and BRS 506 had $\mathrm{pH}$ values ranging between 3.8 and 4.2, indicating good quality silage. Overall, the sorghum hybrids 9929030, 12F042224, 12F042150, FEPAGRO19, and FEPAGRO11 had the best growth and production characteristics, and plant and silage chemical composition, and are thus recommended for the production of silage in the semiarid of northeastern Brazil.
\end{abstract}

Key words: Chemical characteristics. Nutritional value. Productivity. Semiarid. Sorghum bicolor.

1 Discente do Curso de Doutorado do Programa de Pós-Graduação em Ciência Animal, PPGCA, Universidade Federal do Piauí, UFPI, Teresina, PI, Brasil. E-mail: romilda0155@hotmail.com

2 Profs., UFPI, Departamento de Zootecnia, Bom Jesus, PI, Brasil. E-mail: edvan@ufpi.edu.br; jacome@ufpi.edu.br

3 Prof., Universidade Federal de Campina Grande, UFCG, Centro de Saúde e Tecnologia Rural, Patos, PB, Brasil. E-mail: jmpfpiaui@gmail.com

4 Pesquisador, Empresa Brasileira de Pesquisa Agropecuária, EMBRAPA Milho e Sorgo, Sete Lagoas, MG, Brasil. E-mail: javelinorod@gmail.com

5 Discente do Curso de Doutorado do Programa de Doutorado Integrado em Zootecnia, Universidade Federal da Paraíba, UFPB, Departamento de Zootecnia, Areia, PB. Brasil. E-mail: alex.lopes77@hotmail.com

6 Discente do Curso de Doutorado do Programa de Pós-Graduação em Zootecnia Tropical, PPGZT, UFPI, Bom Jesus, PI, Brasil. E-mail: keuvensantos03@gmail.com

7 Discente do Curso de Graduação em Zootecnia, CBZ, UFPI, Bom Jesus, PI, Brasil. E-mail: caiozootecc@gmail.com

* Author for correspondence 


\section{Resumo}

O objetivo deste estudo foi identificar híbridos de sorgo para produção de silagem em Clima Semiárido no Nordeste do Brasil. Vinte e três híbridos foram avaliados em delineamento em blocos casualizados com três repetições. Em relação à planta, foram avaliados o rendimento de Massa seca: Folhas, caule, panícula, grãos e material morto, bem como a composição química. Quanto à silagem, foram avaliados o pH, o nitrogênio amoniacal (N-NH3) e a composição química. Os híbridos 947252, FEPAGRO 18, 12F042226, e SF 11 apresentaram melhor caracterização morfológica, Devido a maior quantidade de folhas e grãos. O híbrido FEPAGRO 19 apresentou o maior valor de matéria seca, 443,3 $\pm 17,0 \mathrm{~g} \mathrm{~kg}^{-1} \mathrm{e}$ o híbrido 12F042496, o menor valor, 271,3 $\pm 17,0 \mathrm{~g} \mathrm{~kg}^{-1}$. Os demais híbridos apresentaram teores de MS dentro dos valores recomendados para produção de silagem $\left(280 \mathrm{a} 400 \mathrm{~g} \mathrm{~kg}^{-1}\right)$. Em relação à proteína bruta, foram observados níveis mais elevados nos híbridos agrupados 12F042496, 947254 e 12F042422. O híbrido 12F042496 apresentou o maior conteúdo de fibra em detergente neutro. Os híbridos 9929036 , 9929030, 9929012, 947254, 947072, PROG 134 IPA, 12F042226,12F042422, e BRS 506 apresentaram pH dentro Dessa Faixa (3,8 a 4,2), indicando silagem de boa qualidade. Os híbridos de sorgo 9929030, 12F042224, 12F042150, FEPAGRO19 e FEPAGRO11 são recomendados para a produção de silagem na região semiárida (BSh) do Nordeste, pois apresentam melhores características de crescimento e produção, além de melhor composição química de plantas e silagens.

Palavras-chave: Características químicas. Produtividade. Semiárido. Sorghum bicolor. Valor nutricional.

\section{Introduction}

The Sorghum bicolor, commonly known as sorghum, is characterized by high water use efficiency, is tolerant to abiotic stressors such as salinity and water deficit, and has a high biomass production (Tazoe et al., 2016); thus, it is well suited for use in regions of dry climate. Sorghum can be used both for agricultural and livestock purpose and is often used for silage production as it produces high quality silage in large quantities.

Sorghum production allows farmers to maximize yield whilst maintaining feed quality, as it has a high nutritional value and relatively low cost. The production of high-quality silage contributes to the optimization of herd performance index (Rodrigues et al., 2014), increases food security for the herd, and increases animal productivity. Therefore, identifying a suitable sorghum hybrid for the production of high-quality silage is essential.

Morphological characterization of cultivated plants is used to determine the genetic divergence among hybrids, and is used in genetic breeding programs to guide the selection of sorghum plants with high productivity and nutritional value (R.
Silva, Santos, Tabosa, Gomes, \& Almeida, 2012). Productivity and chemical composition of S. bicolor varies significantly owing to the large number of existing hybrids and their different productive abilities. Therefore, it is important to evaluate the hybrids currently available on the market and being developed, in order to identify those that meet the requirements for plant components, biomass production, and nutritional value for animal feeding and silage production (Sher, Hassan, Ali, Hussain, \& Sattar, 2017).

The Köppen climate classification is used to classify the climate in different regions of the world. The climate type BSh is characterized as hot and semiarid, with rainy summers and dry winters (Medeiros, Santos, Sousa, \& Gomes, 2013). Sorghum cultivation is recommended for regions with a BSh climate, where maize (Zea mays) often does not achieve adequate growth. This study was developed with the objective of identifying hybrids of sorghum for the production of silage in the semiarid regions of northeastern Brazil. The findings can also be applied to other locations with a similar climatic classification. 


\section{Material and Methods}

\section{Experimental location}

The experiment was carried out between November 2014 and April 2015 at the School Farm Alvorada do Gurgueia on the Professor Cinobelina Elvas Campus (CPCE) in Alvorada do Gurgueia, Piauí, Brazil $\left(08^{\circ} 25^{\prime} 28^{\prime \prime} \mathrm{S} 4^{\circ} 46^{\prime} 38^{\prime \prime} \mathrm{W} ; 281 \mathrm{~m}\right.$ elevation). The climate of this region is classified as BSh following Köppen and Geiger (1928), and is hot and semiarid, with rainy summers and dry winters. Data on rainfall, air relative humidity, and maximum and minimum temperatures during the experimental period were obtained from the Instituto Nacional de Meteorologia [INMET] (2014) and are shown in Figure 1.

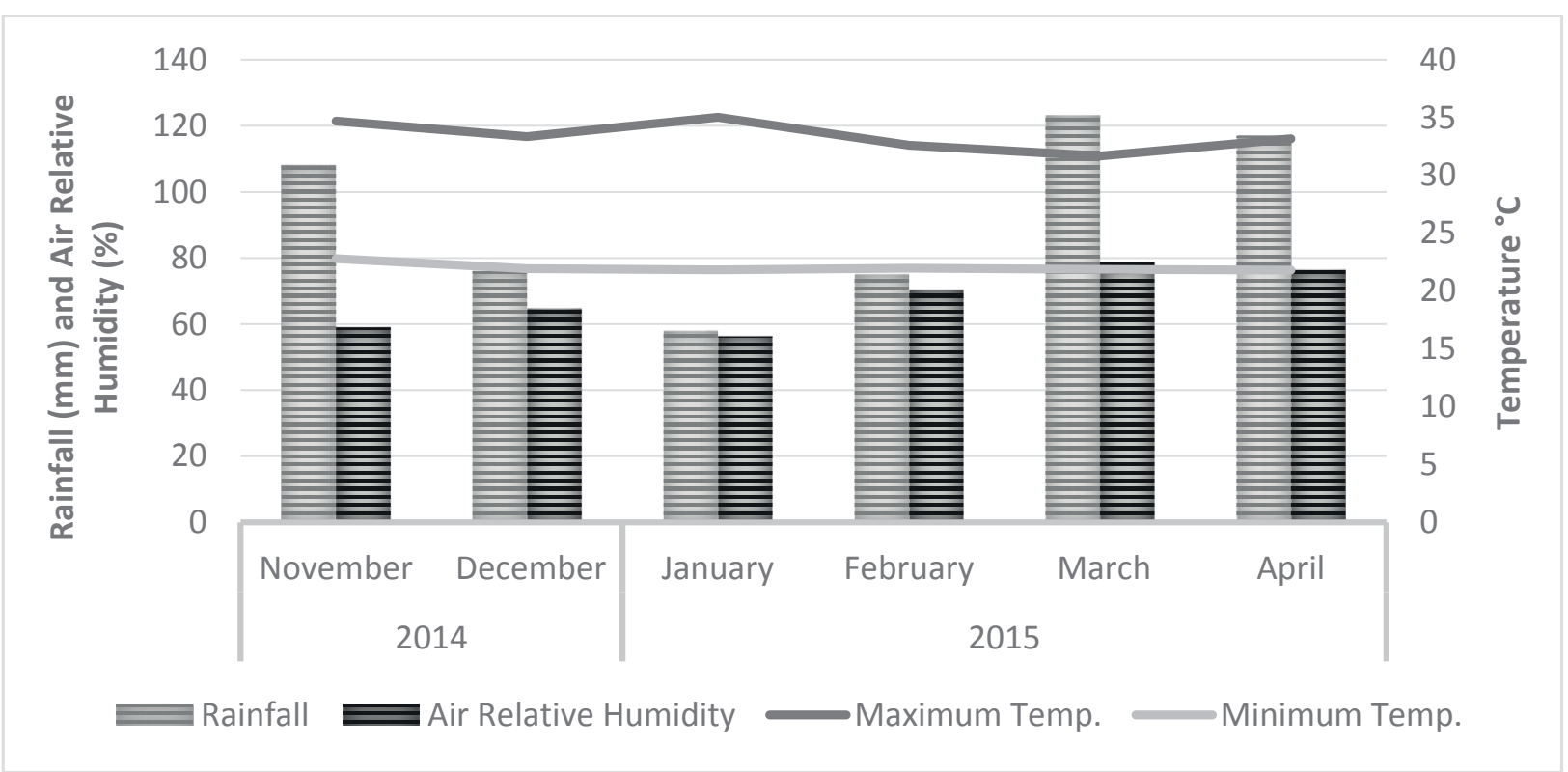

Figure 1. Meteorological data for the cultivation period of the sorghum hybrids from November 2014 to April 2015. Source: http://www.inmet.gov.br/portal/index.php?r=bdmep/bdmep. Station: 82870 - Vale do Gurgueia Cristino Castro, Piauí.

\section{Experimental design, area, and hybrids tested}

The experimental design consisted of randomized blocks with three replicates. The total experimental area was $458.8 \mathrm{~m}^{2}$, and was divided into 75 plots of $2.8 \mathrm{~m}^{2}(2.8 \mathrm{~m} \times 1 \mathrm{~m})$ with $0.70 \mathrm{~m}$ between rows. The plots were separated by non-cultivated spaces of $0.5 \mathrm{~m}$ and there were $2 \mathrm{~m}$ between blocks.

Twenty-five hybrids were cultivated: 9929036 , 9929030, 12F042224, 12F042150, FEPAGRO 18, FEPAGRO 19, FEPAGRO 11, 9929012, 9929026, 947216, 947030, 947254, 947072, 947252, SF 15, SF 11, SF 25, PROG 134 IPA, 12F042140, 12F042066, 12F042226, 12F042422, 12F042496,
BRS 506 and BRS Ponta Negra, provided by Embrapa Corn and Sorghum, and classified as double purpose sorghums.

\section{Planting and fertilization}

Before the experiment begun, a soil sample from the $0-20 \mathrm{~cm}$ layer of the experimental area was collected for analysis and chemical characterization (carried out at the Soil Analysis Center, CPCE). The soil was classified as dystrophic yellow latosol, following Raij (1991), and had the following characteristics: $\mathrm{pH}=5.40$; phosphorus $(\mathrm{P})=9.6$ $\mathrm{mg} \mathrm{dm}{ }^{-3}$; potassium $(\mathrm{K})=21.19 \mathrm{mg} \mathrm{dm}^{-3}$; calcium 
$(\mathrm{Ca})=2.4 \mathrm{cmol} \mathrm{dm}^{-3}$; magnesium $(\mathrm{Mg})=0.6 \mathrm{cmol}$ $\mathrm{dm}^{-3} ;$ aluminum $(\mathrm{Al})=0.0 \mathrm{cmol} \mathrm{dm}^{-3} ;$ hydrogen + aluminum $(\mathrm{H}+\mathrm{Al})=3.5 \mathrm{cmol} \mathrm{dm}^{-3}$; sum of bases $(\mathrm{SB})=3.1 \mathrm{cmol} \mathrm{dm}^{-3} ;$ Effective CEC $(\mathrm{t})=3.1 \mathrm{cmol}$ $\mathrm{dm}^{-3}$; CEC at $\mathrm{pH} 7.0(\mathrm{~T})=6.5 \mathrm{cmol} \mathrm{dm}^{-3}$; saturation $(\mathrm{V})=46.8 \%$, saturation by aluminum $(\mathrm{m})=0.0 \%$, and organic matter $(\mathrm{OM})=0.0 \%$.

Based on the soil base saturation and crop requirements, it was not necessary to perform soil correction based on the soil base saturation. For the base fertilization $50 \mathrm{~kg} \mathrm{~N}$ ha-1 (urea), 50 $\mathrm{kg} \mathrm{K} \mathrm{ha} \mathrm{K}^{-1}$ (potassium chloride), and $30 \mathrm{~kg} \mathrm{P} \mathrm{ha}{ }^{-1}$ (single superphosphate) was applied, following the recommendations of Sousa and Lobato (2004). Planting was done at the beginning of the rainy season by sowing 20 seeds $\mathrm{m}^{-1}$.

\section{Assessment of production}

Assessments of productivity were carried out according to the phenological stage of the plant, at the hard dough stage. Each plant was cut at a height of $10 \mathrm{~cm}$ from the soil. The lateral rows that were considered borders were discarded, and only the plants from the useful area of each plot (2 central linear meters) were retained for analysis.

The sorghum hybrids were planted on November $15^{\text {th }}, 2014$, with harvesting and growing periods outlined as follows: the hybrids 9929036, 9929030 , 9929026, and 12F042226 were cut on March $2^{\text {nd }}, 2015$, with a cycle of 105 days; the hybrids 12F042224, 12F042150, FEPAGRO 18, FEPAGRO 19, FEPAGRO 11, 9929012, 947216, 947030, 947072, and 947252 were cut on March $14^{\text {th }}, 2015$, with a cycle of 119 days; the hybrids 947254 and 12F042066 were cut on March 22 $2^{\text {nd }}, 2015$, with a cycle of 126 days; the hybrids SF 11, PROG 134 IPA, 1141570, 1141562, and BRS 506 were cut on March $28^{\text {th }}, 2015$, with a cycle of 132 days; and the hybrids SF 15 and SF 25 were cut on April $4^{\text {th }}$, 2015, with a cycle of 138 days, according to the phenological stage of the plant.
The material from the useful area of each plot ( 2 central linear meters, $0.5 \mathrm{~m}^{2}$ ) was harvested and weighed in the field using a high-precision digital scale (to $10 \mathrm{~kg}$ ), to obtain the total fresh mass. The material was then chopped in a stationary forage chopper (model EN-12B ${ }^{\circledR}$ ), which had been adjusted to chop the material into 2 to $3 \mathrm{~cm}$ pieces. A $500 \mathrm{~g}$ sample was placed in a forced ventilation oven at $55{ }^{\circ} \mathrm{C}$ for $72 \mathrm{~h}$ to determine the pre-dried weight, following which the total dry mass yield $\left(\mathrm{t} \mathrm{ha}^{-1}\right)$ was calculated.

In addition, the total leaf dry mass yield ( $\mathrm{t}$ ha$\left.{ }^{1}\right)$, total stem dry mass $\left(\mathrm{t} \mathrm{ha}^{-1}\right)$, total panicle dry mass $\left(\mathrm{t} \mathrm{ha}^{-1}\right)$, total grain dry mass $\left(\mathrm{t} \mathrm{ha}^{-1}\right)$, and total senescent matter dry mass $\left(\mathrm{t} \mathrm{ha}^{-1}\right)$ were determined through morphological fractionation.

\section{Silage production}

The plant forage mass was processed using a stationary forage shredder and was cut into pieces of 2-2.5 cm. For Silage Storage, experimental PVC silos $(50 \mathrm{~cm} \times 10 \mathrm{~cm})$ used and properly closed. An average of $3.0 \pm 0.1 \mathrm{~kg}$ of fresh forage mass was placed in each silo, reaching an average density of $500 \pm 30 \mathrm{~kg} \mathrm{~m}^{-3}$ of natural matter. To estimate the density of the silage, silos were weighed before and after the forage was placed inside (Jobim, Nussio, Reis, \& Schmidt, 2007). After 30 days, the silos were opened and a sample of approximately 500 $\mathrm{g}$ was extracted and placed in a forced ventilation oven at $55^{\circ} \mathrm{C}$ for $72 \mathrm{~h}$ to determine the pre-dried weight at opening.

\section{Chemical composition of the whole plant and silages of hybrids}

At the opening of the experimental silo, a portion of the silage (duplicate) was used fresh to evaluate the $\mathrm{pH}$ (Mizubuti, Pinto, Pereira, \& Ramos, 2009), and the reading was performed with a $\mathrm{pH}$ meter (MA522 Marconi Laboratory Equipment, Piracicaba, Brazil). Ammoniacal nitrogen ( $\mathrm{mg} \mathrm{g}^{-1}$ 
total $\mathrm{N}$ ) was determined following the methodology described by Bolsen et al. (1992).

The pre-dried samples of the whole plant and silages were ground in a Thomas Wiley ${ }^{\circledR}$ stationary mill with a $1 \mathrm{~mm}$ mesh sieve in preparation for laboratory analysis of chemical composition.

Analyses of dry matter (DM) ( $\mathrm{n}^{\circ}$ 934.01), mineral matter $(\mathrm{MM})\left(\mathrm{n}^{\circ} 930.05\right)$, and crude protein (CP) (n ${ }^{\circ}$ 981.10) were performed according to the Association of Official Analitycal Chemists [AOAC] (1990) methods. Analyses of neutral (NDF) and acid (ADF) detergent fiber (using $\alpha$-amylase) were performed following the methods proposed by Van Soest, Robertson, and Lewis (1991). These analyses were carried out at the Federal University of Campina Grande Animal Nutrition Laboratory in Patos.

The total digestible nutrient value for both the sorghum whole plant and silage was determined, taking into account the aNDF and ADF, using the following equations: aTDN: $91.0246-0.57188^{*}$ $a N D F$, following Cappelle, Valadares, Silva and Cecon (2001).

\section{Statistical analysis}

The data were analyzed by analysis of variance using the clustering method of Scott \& Knot, with the software SISVAR version 5 (Ferreira, 2011). Significance was determined at the level of $5 \%$.

\section{Results and Discussion}

Production of dry mass and fractionated forage

Among the hybrids, 947252 had the highest ( $\mathrm{p}<$ $0.01)$ total dry mass forage yield (TDFM), at 36.1 $\pm 3.8 \mathrm{tha}^{-1}$ (Table 1 ). The productivity of TDFM is primarily a function of the management method, the productive capacity of the variety, its adaptability to its edaphoclimatic environment, and the climatic factors during the experimental period.

The observed results (Table 1) were higher for many characteristics than those found by Perazzo et al. (2013), who evaluated the agronomic characteristics and rainfall use efficiency of sorghum cultivars in the semi-arid regions of Brazil. Perazzo et al. (2013) reported that the cultivar BRS Ponta Negra had a green mass yield of $52.1 \mathrm{t} \mathrm{ha}^{-1}$, dry mass yield of $12.0 \mathrm{t} \mathrm{ha}^{-1}$ and plant height of 2.74; the hybrid 947252 had the highest productivity, which was related to its superior height, proportion of leaves and plant green mass content at the moment of the harvest.

The hybrids SF 15, 12F042226, SF 11, 947072, 947252, 947030, 12F042422, 12F042066, SF 25, 12F042150, 12F042224, FEPAGRO 18, PROG 134 IPA, 9929012, and 9929026 were grouped in terms of having the highest leaf mass yield $(\mathrm{p}<0.01)$, with values ranging from $4.82 .3 \pm 0.7 \mathrm{tha}^{-1}$. This result is significant as the leaves are the most important portion of the plant for animal feeding in terms of quantity and quality. 
Table 1

Production of dry and fractioned forage mass of the sorghum hybrids

\begin{tabular}{lcccccc}
\hline Hybrid & TDFM & Leaf & Stem & Panicle & Grain & DM $^{2}$ \\
& & \multicolumn{2}{c}{$\left(\mathrm{t} \mathrm{ha}^{-1}\right)$} & & \\
\hline 9929036 & $13.3 \mathrm{c}$ & $0.7 \mathrm{~b}$ & $8.4 \mathrm{c}$ & $1.7 \mathrm{~b}$ & $1.3 \mathrm{a}$ & $1.0 \mathrm{~b}$ \\
9929030 & $13.9 \mathrm{c}$ & $0.9 \mathrm{~b}$ & $8.9 \mathrm{c}$ & $3.4 \mathrm{~b}$ & $0.2 \mathrm{~b}$ & $0.5 \mathrm{c}$ \\
12 F042224 & $18.9 \mathrm{~b}$ & $2.9 \mathrm{a}$ & $8.9 \mathrm{c}$ & $3.7 \mathrm{~b}$ & $2.2 \mathrm{a}$ & $0.9 \mathrm{~b}$ \\
12F042150 & $22.0 \mathrm{~b}$ & $3.0 \mathrm{a}$ & $13.4 \mathrm{~b}$ & $3.1 \mathrm{~b}$ & $0.6 \mathrm{~b}$ & $1.6 \mathrm{a}$ \\
FEPAGRO 18 & $20.4 \mathrm{~b}$ & $2.8 \mathrm{a}$ & $11.8 \mathrm{~b}$ & $3.4 \mathrm{~b}$ & $2.0 \mathrm{a}$ & $0.3 \mathrm{c}$ \\
FEPAGRO 19 & $15.4 \mathrm{c}$ & $2.0 \mathrm{~b}$ & $6.4 \mathrm{c}$ & $4.1 \mathrm{~b}$ & $1.7 \mathrm{a}$ & $0.9 \mathrm{~b}$ \\
FEPAGRO 11 & $10.7 \mathrm{c}$ & $1.4 \mathrm{~b}$ & $6.8 \mathrm{c}$ & $1.3 \mathrm{~b}$ & $0.8 \mathrm{~b}$ & $0.5 \mathrm{c}$ \\
9929012 & $14.1 \mathrm{c}$ & $2.4 \mathrm{a}$ & $7.9 \mathrm{c}$ & $2.9 \mathrm{~b}$ & $0.5 \mathrm{~b}$ & $0.2 \mathrm{c}$ \\
9929026 & $16.9 \mathrm{c}$ & $2.3 \mathrm{a}$ & $10.2 \mathrm{~b}$ & $3.4 \mathrm{~b}$ & $0.3 \mathrm{~b}$ & $0.5 \mathrm{c}$ \\
947216 & $8.0 \mathrm{c}$ & $0.7 \mathrm{~b}$ & $4.4 \mathrm{c}$ & $2.4 \mathrm{~b}$ & $0.1 \mathrm{~b}$ & $0.2 \mathrm{c}$ \\
947030 & $20.2 \mathrm{~b}$ & $3.4 \mathrm{a}$ & $10.7 \mathrm{~b}$ & $4.2 \mathrm{~b}$ & $1.0 \mathrm{~b}$ & $0.9 \mathrm{~b}$ \\
947254 & $14.9 \mathrm{c}$ & $1.8 \mathrm{~b}$ & $8.5 \mathrm{c}$ & $2.9 \mathrm{~b}$ & $1.0 \mathrm{~b}$ & $0.6 \mathrm{c}$ \\
947072 & $20.8 \mathrm{~b}$ & $3.6 \mathrm{a}$ & $11.7 \mathrm{~b}$ & $3.7 \mathrm{~b}$ & $1.1 \mathrm{a}$ & $0.6 \mathrm{c}$ \\
947252 & $36.1 \mathrm{a}$ & $3.5 \mathrm{a}$ & $20.7 \mathrm{a}$ & $7.0 \mathrm{a}$ & $0.5 \mathrm{~b}$ & $2.0 \mathrm{a}$ \\
SF 15 & $22.6 \mathrm{~b}$ & $4.8 \mathrm{a}$ & $10.4 \mathrm{~b}$ & $5.9 \mathrm{a}$ & $0.1 \mathrm{~b}$ & $1.2 \mathrm{~b}$ \\
SF 11 & $23.6 \mathrm{~b}$ & $3.8 \mathrm{a}$ & $14.3 \mathrm{~b}$ & $4.8 \mathrm{a}$ & $0.0 \mathrm{~b}$ & $0.5 \mathrm{c}$ \\
SF 25 & $15.2 \mathrm{c}$ & $3.0 \mathrm{a}$ & $7.8 \mathrm{c}$ & $3.5 \mathrm{~b}$ & $0.1 \mathrm{~b}$ & $0.5 \mathrm{c}$ \\
PROG 134 IPA & $13.9 \mathrm{c}$ & $2.9 \mathrm{a}$ & $6.8 \mathrm{c}$ & $3.1 \mathrm{~b}$ & $0.0 \mathrm{~b}$ & $0.9 \mathrm{~b}$ \\
12 F042066 & $20.2 \mathrm{~b}$ & $3.1 \mathrm{a}$ & $13.0 \mathrm{~b}$ & $2.8 \mathrm{~b}$ & $0.5 \mathrm{~b}$ & $0.6 \mathrm{c}$ \\
12 F042226 & $22.6 \mathrm{~b}$ & $4.0 \mathrm{a}$ & $12.5 \mathrm{~b}$ & $4.7 \mathrm{a}$ & $0.3 \mathrm{~b}$ & $1.0 \mathrm{~b}$ \\
12 F042422 & $18.7 \mathrm{~b}$ & $3.2 \mathrm{a}$ & $10.8 \mathrm{~b}$ & $3.6 \mathrm{~b}$ & $0.7 \mathrm{~b}$ & $0.3 \mathrm{c}$ \\
12 F042496 & $18.9 \mathrm{~b}$ & $0.4 \mathrm{~b}$ & $10.4 \mathrm{~b}$ & $5.6 \mathrm{a}$ & $2.3 \mathrm{a}$ & $0.1 \mathrm{c}$ \\
BRS 506 & $10.2 \mathrm{c}$ & $1.5 \mathrm{~b}$ & $5.6 \mathrm{c}$ & $2.2 \mathrm{~b}$ & $0.2 \mathrm{~b}$ & $0.7 \mathrm{c}$ \\
\hline P - value & $<0.01$ & $<0.01$ & $<0.01$ & $<0.01$ & $<0.01$ & $<0.01$ \\
SEM & 3.8 & 0.7 & 2.3 & 0.8 & 0.4 & 0.2 \\
\hline
\end{tabular}

${ }^{1}$ TDFM: total dry forage mass; ${ }^{2} \mathrm{DM}$ : dead matter; ${ }^{3} \mathrm{EPM}$ : standard error of the mean. Means followed by equal letters in the same column do not differ from each other by the Scott-Knot procedure, at the significance level of $\mathrm{p}<0.05$. 
The hybrid 947252 had the highest stem mass yield $(\mathrm{p}<0.01)$, at $20.7 \pm 2.3 \mathrm{t} \mathrm{ha}^{-1}$. The other hybrids obtained lower mean values ranging from 14.3 to $4.4 \pm 2.3 \mathrm{t} \mathrm{ha}^{-1}$. As for the panicle mass yield, the hybrids 947252 , SF 15, 12F042496, SF 11 , and $12 \mathrm{~F} 042226$ had values of $7.0,5.9,5.6,4.8$, and $4.7 \pm 0.8 \mathrm{t} \mathrm{ha}^{-1}$, respectively $(\mathrm{p}<0.01)$. High stem production is associated with plant height (e.g. the hybrid 947252 had a height of $234.8 \mathrm{~cm}$ ). However, quantity may compromise the quality of the plant's nutritional value since this fraction had lower coefficients of digestibility (Machado \& Valle, 2012).

For grain production, the hybrids 9929036, 12F042224, FEPAGRO 18, FEPAGRO 19, 12F042496, and 947072 were grouped with the highest values $(\mathrm{p}<0.01)$, at 2.3, 2.2, 2.0, 1.7, 1.3, and $1.1 \pm 0.4 \mathrm{tha}^{-1}$, respectively, which are related to the amount of panicle. The hybrids SF 11 and PROG 134 IPA did not have grains as they were consumed by birds. The result of grain consumption by birds is important for choosing the correct sorghum hybrid for silage production, as the absence of grain compromises the quality of the silage (A. L. Silva et al., 2019).

A higher panicle participation is a desirable characteristic because it allows for a greater grain yield and higher nutritive value of the silage. In addition, dual-purpose forage hybrids can combine mass and grain yield, which highlights the importance of panicle production (A. L. Silva et al., 2020).

The highest amount of dead matter was obtained from hybrids 947252 and 12F042150 ( $<0.01)$, at 2.0 and $1.6 \pm 0.2 \mathrm{t} \mathrm{ha}^{-1}$, respectively. This could be attributed to the accelerated cycle of these hybrids in response to the climatic conditions, which ultimately caused them to produce a poor quality forage. Alves et al. (2016) evaluated sorghum cultivars for grain production and found variations in grain yield from 1.85 to $2.87 \mathrm{t} / \mathrm{ha}$ among the tested materials, which was higher than the mean values obtained in the present study.

\section{Chemical composition of the hybrids.}

Regarding the dry matter (DM) of the hybrids ( $p<0.01$ ), hybrid FEPAGRO 19 had the highest dry matter value, at $443.3 \pm 17.0 \mathrm{~g} \mathrm{~kg}^{-1}$, and hybrid $12 \mathrm{~F} 042496$ had the lowest value $\left(271.3 \pm 17.0 \mathrm{~g} \mathrm{~kg}^{-}\right.$ $\left.{ }^{1}\right)$. (Table 2). The DM content of the other hybrids fell within the recommended values for silage production (280 to $400 \mathrm{~g} \mathrm{~kg}^{-1}$ ). DM values below $280 \mathrm{~g} \mathrm{~kg}^{-1}$ favor the fermentation of Clostridium spp., and values higher than $400 \mathrm{~g} \mathrm{~kg}^{-1}$ may cause difficulties in compression and result in higher air storage in the silo (Tolentino et al., 2016). There was no difference $(\mathrm{P}=0.16)$ in the mineral matter content between the sorghum hybrids. 
Table 2

Chemical composition of the sorghum hybrids

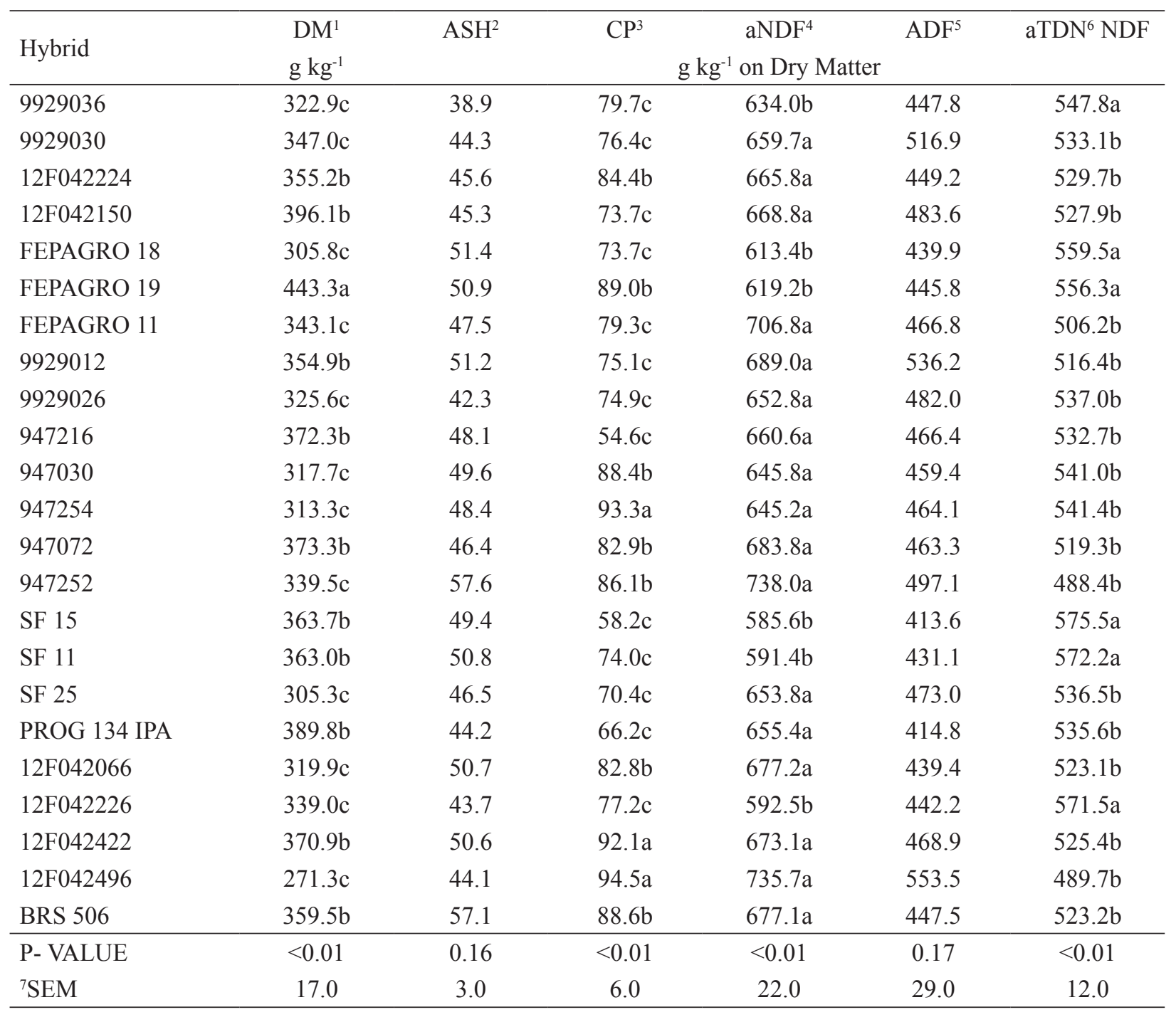

${ }^{1}$ Dry matter; ${ }^{2}$ Ashes; ${ }^{3}$ Crude protein; ${ }^{4}$ Neutral detergent fiber; ${ }^{5}$ Acid detergent fiber; ${ }^{6}$ Total digestible nutrients in the neutral detergent fiber; ${ }^{7}$ SEM: Standard error of the mean. Means followed by equal letters in the same column do not differ from each other based on the Scott-Knot clustering method, at the significance level of $\mathrm{p}<0.05$.

Regarding crude protein content (CP), higher values were observed in the hybrids 12F042496, 947254, and 12F042422, which had means of 94.5, 93.3, and $92.2 \pm 6.0 \mathrm{~g} \mathrm{~kg}^{-1}$, respectively. These variations in CP content are likely due to the differences in the proportion of stem, leaves, and panicle, because the proportion of these components in the plant directly influences the $\mathrm{CP}$ content (Moura et al., 2017).
The observed protein mean values were similar to those found by Mabelebele, Siwela, Gous and Iji (2015) in the grains of grain production hybrids, which ranged from 81 to $95 \mathrm{~g} \mathrm{~kg}^{-1}$. Albuquerque, Pinho, Rodrigues and Brant (2011) studied different sorghum cultivars and found ADF values between 288.3 and $383.7 \mathrm{~g} \mathrm{~kg}^{-1}$.

For the variable neutral detergent fiber content (aNDF), the hybrid 12F042496 had a mean of 
$735.7 \mathrm{~g} \mathrm{~kg}^{-1}$ and was grouped with the other hybrids that obtained the highest values of aNDF. The remaining hybrids with lower values of aNDF were grouped, and the hybrid SF15 had a mean value of $585.6 \mathrm{~g} \mathrm{~kg}^{-1}$. The increase in ADF and NDF ratios hinders digestion and reduces crude protein content (Oliveira et al., 2010).

\section{Chemical characteristics of silages}

The $\mathrm{pH}$ of the silages from the hybrids (Table 3) $9929026,12 \mathrm{~F} 042496,12 \mathrm{~F} 042224,12 \mathrm{~F} 042150$, 947252, SF15, SF11, and 12F042066 were grouped as they had higher values, ranging from 5.5 to $4.7 \pm 0.2$. At $\mathrm{pH}$ values above 4.5 , undesirable fermentation occurs because of the action of deteriorating microorganisms (Veriato et al., 2018). The $\mathrm{pH}$ of good quality silage ranges from 3.8 to 4.2 (Rodrigues et al., 2014). The $\mathrm{pH}$ of the hybrids 9929036, 9929030, 9929012, 947254, 947072, PROG 134I PA, 12F042226, 12F042422, and BRS 506, were within this range. The hybrids FEPAGRO 19, FEPAGRO 11, and 12F042422 had $\mathrm{pH}$ values below this range.

In terms of the ammoniacal nitrogen content $\left(\mathrm{N}-\mathrm{NH}_{3}\right)$ of silages produced as sorghum hybrids, the values ranged from $1.0 \%$ to $3.8 \% \pm 0.1 \%$ and no significant difference was observed $(p=0.65)$. Monteiro, Abreu, Cabral, Ribeiro and Reis (2011) classified silages with levels of N-NH3 below $12 \%$ as good quality; thus, all silages in this study were of good quality. This fact also indicates low intensity of proteolysis during the fermentation process (Tyrolová, Bartoň, \& Loučka, 2017). Thus, all hybrids had $\mathrm{N}-\mathrm{NH}_{3}$ mean values considered ideal for good quality silage.
The hybrids PROG 134 IPA, FEPAGRO 19, FEPAGRO 11, 12F042224, 9929012, 9929026, and 947216 were grouped as having the highest silage dry matter content $(p<0.01)$, with values ranging from 417.2 to $371.0 \pm 18$ and $2 \mathrm{~g} \mathrm{~kg}^{-1}$ (Table 3). The genetic traits of the hybrids that are mainly influenced by the condition of the soil, climate, and age of cut, modify the morphological characteristics of the plant that contribute to changes in the dry matter content (Moraes, Jobim, Silva, \& Marquardt, 2013).

Regarding the mineral matter content, the highest content was observed in the hybrids 947254 , 947072, BRS 506, 12F042226, 9929030, 9929012 , FEPAGRO 11, SF 15, SF 25, and 947030, with mean values ranging from 79.6 to $61.7 \pm 5.0 \mathrm{~g} \mathrm{~kg}^{-1}$. The mineral matter content observed in the present study is similar to the values obtained by Tolentino et al. (2016) $\left(54.6 \mathrm{~g} \mathrm{~kg}^{-1}\right)$.

For the variable crude protein content (CP), the hybrids SF 15, 947072, and 947030 were grouped with the highest values, at 96.2 96.0, and 92.2 \pm 3.0 $\mathrm{g} \mathrm{kg}^{-1}$, respectively. The $\mathrm{CP}$ content is related to the agronomic behavior of the genotype. Because these plants are dual purpose hybrids, they have shorter stems with a higher proportion of leaves and grains, which as well as the stage of maturity and soil and climate conditions of the growing area, contribute to this characteristic (A. L. Silva et al., 2020). The $\mathrm{CP}$ content values were similar to those obtained by Albuquerque, Jardim, Alves, Guimarães and Porto (2013), who studied different sorghum cultivars, and found higher values of CP between 76.8 and $91.6 \mathrm{~g} \mathrm{~kg}^{-1}$ in the $2006 / 2007$ crop. 
Table 3

Chemical characteristics of the silages from the sorghum hybrids

\begin{tabular}{|c|c|c|c|c|c|c|c|c|}
\hline \multirow[t]{2}{*}{ Hybrid } & \multirow[t]{2}{*}{$\mathrm{pH}$} & \multirow{2}{*}{$\begin{array}{c}\mathrm{N}-\mathrm{NH}_{3} \\
(\%)^{1}\end{array}$} & \multirow{2}{*}{$\begin{array}{c}\mathrm{DM} \\
(\%)^{2} \\
\mathrm{~g} \mathrm{~kg}^{-1}\end{array}$} & $\begin{array}{l}\text { ASH } \\
(\%)^{3}\end{array}$ & $\begin{array}{l}\mathrm{CP} \\
(\%)^{4}\end{array}$ & $\begin{array}{c}\text { aNDF } \\
(\%)^{5}\end{array}$ & $\begin{array}{l}\text { ADF } \\
(\%)^{6}\end{array}$ & \multirow[t]{2}{*}{$\begin{array}{l}\text { aTDN } \\
\text { NDF }^{7}\end{array}$} \\
\hline & & & & \multicolumn{4}{|c|}{$\mathrm{g} \mathrm{kg}^{-1}$ on Dry Matter } & \\
\hline 9929036 & $4.1 b$ & 2.0 & $338.7 \mathrm{~b}$ & $48.0 \mathrm{~b}$ & $88.6 \mathrm{~b}$ & $633.1 \mathrm{a}$ & $559.0 \mathrm{~b}$ & $573.9 a$ \\
\hline 9929030 & $3.9 \mathrm{~b}$ & 2.1 & $301.3 b$ & $62.7 \mathrm{a}$ & $89.0 \mathrm{~b}$ & $542.5 \mathrm{~b}$ & $650.5 \mathrm{a}$ & $600.2 a$ \\
\hline $12 \mathrm{~F} 042224$ & $4.5 \mathrm{a}$ & 3.3 & $384.6 \mathrm{a}$ & $57.2 \mathrm{~b}$ & $75.1 \mathrm{c}$ & $655.2 \mathrm{a}$ & $600.8 \mathrm{a}$ & $535.7 \mathrm{~b}$ \\
\hline $12 \mathrm{~F} 042150$ & $4.7 \mathrm{a}$ & 2.1 & $313.1 \mathrm{~b}$ & $45.6 \mathrm{~b}$ & $62.7 \mathrm{~d}$ & $680.2 \mathrm{a}$ & $646.2 \mathrm{a}$ & $521.4 \mathrm{~b}$ \\
\hline FEPAGRO 18 & $4.5 \mathrm{a}$ & 2.1 & $314.1 b$ & $49.2 b$ & $82.7 \mathrm{~b}$ & $579.1 \mathrm{~b}$ & $508.1 \mathrm{~b}$ & $579.2 \mathrm{a}$ \\
\hline FEPAGRO 19 & $3.3 \mathrm{c}$ & 2.3 & $405.9 \mathrm{a}$ & $49.0 \mathrm{~b}$ & $81.4 \mathrm{c}$ & $610.3 b$ & $545.5 \mathrm{~b}$ & $561.4 \mathrm{a}$ \\
\hline FEPAGRO 11 & $3.2 \mathrm{c}$ & 3.8 & $388.3 \mathrm{a}$ & $60.6 \mathrm{a}$ & $77.7 \mathrm{c}$ & $675.7 \mathrm{a}$ & $674.4 \mathrm{a}$ & $524.0 \mathrm{~b}$ \\
\hline 9929012 & $3.7 \mathrm{~b}$ & 2.6 & $371.6 \mathrm{a}$ & $63.4 \mathrm{a}$ & $81.1 \mathrm{c}$ & $624.2 \mathrm{a}$ & $628.7 \mathrm{a}$ & $530.5 b$ \\
\hline 9929026 & $5.5 \mathrm{a}$ & 2.9 & $355.8 \mathrm{a}$ & $48.6 \mathrm{~b}$ & $70.8 \mathrm{~d}$ & $628.9 \mathrm{a}$ & $631.4 \mathrm{a}$ & $550.8 \mathrm{~b}$ \\
\hline 947216 & $5.3 \mathrm{a}$ & 1.9 & $364.3 \mathrm{a}$ & $50.3 \mathrm{~b}$ & $76.6 \mathrm{c}$ & $637.6 \mathrm{a}$ & $573.0 \mathrm{~b}$ & $545.8 b$ \\
\hline 947030 & $4.6 \mathrm{a}$ & 2.0 & $315.1 b$ & $61.7 \mathrm{a}$ & $92.2 \mathrm{a}$ & $558.0 \mathrm{~b}$ & $550.4 \mathrm{~b}$ & $591.2 \mathrm{a}$ \\
\hline 947254 & $4.1 \mathrm{~b}$ & 2.1 & $346.0 \mathrm{~b}$ & $79.6 \mathrm{a}$ & $84.2 \mathrm{~b}$ & $651.0 \mathrm{a}$ & $652.8 \mathrm{a}$ & $538.1 \mathrm{~b}$ \\
\hline 947072 & $4.1 \mathrm{~b}$ & 2.2 & $306.6 \mathrm{~b}$ & $72.3 \mathrm{a}$ & $96.0 \mathrm{a}$ & $655.9 \mathrm{a}$ & $645.9 \mathrm{a}$ & $535.3 b$ \\
\hline 947252 & $4.7 \mathrm{a}$ & 3.4 & $324.1 b$ & $51.1 \mathrm{~b}$ & $86.2 \mathrm{~b}$ & $538.1 \mathrm{~b}$ & $480.0 \mathrm{~b}$ & $602.6 \mathrm{a}$ \\
\hline SF 15 & $4.7 \mathrm{a}$ & 2.3 & $286.5 b$ & $61.1 \mathrm{a}$ & $96.2 \mathrm{a}$ & $629.9 \mathrm{a}$ & $595.7 \mathrm{a}$ & $550.2 b$ \\
\hline SF 11 & $4.6 \mathrm{a}$ & 2.1 & $321.5 b$ & $53.8 \mathrm{~b}$ & $84.4 \mathrm{~b}$ & $645.6 \mathrm{a}$ & $602.3 \mathrm{a}$ & $541.2 b$ \\
\hline SF 25 & $4.3 b$ & 3.3 & $343.7 b$ & $60.6 \mathrm{a}$ & $79.3 c$ & $661.5 \mathrm{a}$ & $650.5 \mathrm{a}$ & $532.2 \mathrm{~b}$ \\
\hline PROG 134 IPA & $3.9 b$ & 1.5 & $417.2 \mathrm{a}$ & $50.5 \mathrm{~b}$ & $73.3 \mathrm{~d}$ & $702.7 \mathrm{a}$ & $680 \mathrm{a}$ & $508.6 \mathrm{~b}$ \\
\hline $12 \mathrm{~F} 042066$ & $4.7 \mathrm{a}$ & 3.2 & $296.1 b$ & $56.4 \mathrm{~b}$ & $80.8 \mathrm{c}$ & $619.5 \mathrm{a}$ & $653.4 \mathrm{a}$ & $556.2 \mathrm{a}$ \\
\hline $12 \mathrm{~F} 042226$ & $3.8 \mathrm{~b}$ & 2.6 & $320.2 b$ & $67.4 \mathrm{a}$ & $78.6 \mathrm{c}$ & $700.1 \mathrm{a}$ & $629.7 \mathrm{a}$ & $510.0 \mathrm{~b}$ \\
\hline $12 \mathrm{~F} 042422$ & $3.2 \mathrm{c}$ & 2.8 & $317.2 \mathrm{~b}$ & $51.7 \mathrm{~b}$ & $84.3 b$ & $649.0 \mathrm{a}$ & $505 \mathrm{~b}$ & $539.3 b$ \\
\hline $12 \mathrm{~F} 042496$ & $5.1 \mathrm{a}$ & 2.8 & $348.7 b$ & $45.0 \mathrm{~b}$ & $70.5 \mathrm{~d}$ & $609.4 \mathrm{~b}$ & $651.6 \mathrm{a}$ & $561.9 \mathrm{a}$ \\
\hline BRS 506 & $4.1 \mathrm{~b}$ & 2.7 & $347.8 \mathrm{~b}$ & $70.2 \mathrm{a}$ & $87.2 \mathrm{~b}$ & $605.0 \mathrm{~b}$ & $499.7 \mathrm{~b}$ & $564.4 \mathrm{a}$ \\
\hline P- VALUE & $<0.01$ & 0.65 & $<0.01$ & $<0.01$ & $<0.01$ & $<0.01$ & $<0.01$ & $<0.01$ \\
\hline${ }^{7} \mathrm{SEM}$ & 0.2 & 0.1 & 18.5 & 5.0 & 3.0 & 27.9 & 26.4 & 16.1 \\
\hline
\end{tabular}

${ }^{1}$ Dry matter; ${ }^{2}$ Ashes; ${ }^{3}$ Crude protein; ${ }^{4}$ Neutral detergent fiber; ${ }^{5}$ Acid detergent fiber; ${ }^{6}$ Total digestible nutrients in the neutral detergent fiber; ${ }^{7}$ SEM: Standard error of the mean. Means followed by equal letters in the same column do not differ from each other based on the Scott-Knot clustering method, at the significance level of $\mathrm{p}<0.05$.

Regarding the silage NDF content, the hybrids PROG 134 IPA, 12F042226, 12F042150, FEPAGRO 11, SF 25, 947072, SF 11, 12F042422, 12F042224, 9929036, 947216, 9929026, 9929012, SF15, and 12F042066 were grouped as having the highest NDF content, which ranged from 619 to $702 \pm 27.9 \mathrm{~g} \mathrm{~kg}^{-1}$. Variation in the aNDF content is attributed to the consumption of nonstructural carbohydrates, carried out mainly by lactic acid bacteria. The lower the aNDF content in the silage, the better the nutritional value and animal consumption (Santos et al., 2013). Values of aNDF values $60 \%$ correlate negatively with dry matter intake by animals (Tolentino et al., 2016).

The highest ADF content was found in the silages from the hybrids 947252 , SF 25, 9929030 , FEPAGRO 11, 12F042150, 947254, 947072 , 9929012, 9929026, 947072, SF 11, and 12F042224, 
and ranged from 600 to $674 \pm 26.4 \mathrm{~g} \mathrm{~kg}^{-1}$. This fraction in some hybrids can be correlated with the production of stems and grains. Albuquerque et al. (2011) studied different sorghum cultivars and found ADF values between 288.3 and $383.7 \mathrm{~g} \mathrm{~kg}^{-1}$.

The observed aTDN values can be explained by the high protein concentrations found in the hybrids. According to D. J. Silva and Queiroz (2002), ADF is an indicator of the digestibility and energetic value of the silage, as the lower the ADF, the higher the amount of digestible nutrients.

\section{Conclusion}

Sorghum hybrids 9929030, 12F042224, 12F042150, FEPAGRO19, and FEPAGRO11 are recommended for the production of silage in regions with a BSh Köppen climate, as they have better growth and production characteristics, as well as better plant and silage chemical compositions.

\section{Acknowledgements}

The authors appreciate the support provided by the Study Group on Forage Crops (NUEFO), too thank the CAPES and FAPEPI for the financial support.

\section{References}

Albuquerque, C. J. B., Jardim, R. R., Alves, D. D., Guimarães, A. D. S., \& Porto, E. M. V. (2013). Características agronômicas e bromatológicas dos componentes vegetativos de híbridos de sorgo forrageiro em Minas Gerais. Revista Brasileira de Milho e Sorgo, 12(2), 164-182. doi: 10.18512/19806477/rbms.v12n2p164-182.

Albuquerque, C. J. B., Pinho, R. G. V., Rodrigues, J. A. S., \& Brant, R. D. S. (2011). Espaçamento entre fileiras e densidade de semeadura do sorgo forrageiro para a região norte de Minas Gerais. Ciência $e$ Agrotecnologia, 35(3), 494-501. doi: 10.1590/ S1413-70542011000300009
Alves, A. R., Pascoal, L. A. F., Cambuí, G. B., Trajano, J. S., Silva, C. M., \& Gois, G. C. (2016). Fibra para ruminantes: aspecto nutricional, metodológico e funcional. PUBVET, 10(7), 568-579. doi: 10.1590/1142 e0e16dd9d3280d9ab0508c86149

Association of Official Analitycal Chemists (1990). Official methods of analysis (15th ed.). Washington D.C. ed. Arlington: AOAC International

Bolsen, K. K., Lin, C., Brent, C. R., Feyerherm, A., Murban, J. E., \& Aimutis, W. R. (1992). Effect of silage additives on the microbial succession and fermentation process of alfalfa and corn silages. Journal of Dairy Science, 75(11), 3066-3083. doi: 10.3168/jds.S0022-0302(92)78070-9.

Cappelle, E. R., Valadares, S. D. C., Fo., Silva, J. D., \& Cecon, P. R. (2001). Estimativas do valor energético a partir de características químicas e bromatológicas dos alimentos. Revista Brasileira de Zootecnia, 30(6), 1837-1856. doi: 10.1590/S151635982001000700022

Ferreira, D. F. (2011). Sisvar: computer statistical analysis system. Ciência e Agrotecnologia, 35(6), 1039-1042. doi: 10.1590/S1413-70542011000600001

Instituto Nacional de Meteorologia (2014). Banco de dados meteorológicos para ensino e pesquisa BDMEP. Brasília: INMET. Recuperado de http:// www.inmet.gov.br/portal/index.php?r=bdmep/ bdmep

Jobim, C. C., Nussio, L. G., Reis, R. A., \& Schmidt, P. (2007). Avanços metodológicos na avaliação da qualidade da forragem conservada. Revista Brasileira de Zootecnia, 36(0), 101-119. doi: 10.1590/ S151635982007001000013 .

Köppen, W., \& Geiger, R. (1928). Klimate der Erde. Gotha: Verlag Justus Perthes.

Mabelebele, M., Siwela, M., Gous, R. M., \& Iji, P. A. (2015). Chemical composition and nutritive value of South African sorghum varieties as feed for broiler chickens. South African Journal Animal Science, 45(2), 206-213. doi: 10.4314/sajas.v45i2.12.

Machado, L. A. Z., \& Valle, C. B. (2012). Desempenho agronômico de híbridos de capim-braquiária em sucessão à soja. Pesquisa Agropecuária Brasileira, 46(11), 1454-1462. doi: 10.1590/S0100-204X2011 001100006.

Medeiros, R. M., Santos, D. C., Sousa, F. A. S., \& Gomes, M. F., Fo. (2013). Análise climatológica, classificação climática e variabilidade do balanço hídrico climatológico na Bacia do Rio Uruçui Preto, PI. Revista Brasileira de Geografia e Física, 6(4), 652-664. doi: 10.7127/RBAI. V6N300088 
Mizubuti, I. Y., Pinto, A. P., Pereira, E. S., \& Ramos, B. M. O. (2009). Métodos laboratoriais de avaliação de alimentos para animais. Londrina: EDUEL.

Monteiro, I. J. G., Abreu, J. G., Cabral, L. S., Ribeiro, M. D., \& Reis, R. H. P. (2011). Elephant grass silage additives with alternative products. Acta Scientiarum, Animal Sciences, 33(4), 347-352. doi: $10.4025 /$ actascianimsci.v33i4.12629.

Moraes, S. D. D., Jobim, C. C., Silva, M. S. D., \& Marquardt, F. I. (2013). Production and chemical composition of hybrid sorghum and corn for silage. Revista Brasileira de Saúde e Produção Animal, 14(4), 624-634. doi: 10.1590/S1519-99402013000400002 .

Moura, M. M. A., Pires, D. A. D. A., Costa, R. F., Tolentino, D. C., Rigueira, J. P. S., \& Sales, E. C. J. D. (2017). Nutritional value of sorghum silages. Acta Scientiarum. Animal Sciences, 39(2), 137-142. doi: 10.4025/actascianimsci.v39i1.32677.

Oliveira, R. D. P., França, A. F. D. S., Miyagi, E. S., Silva, A. G. D., Carvalho, E. R. D., \& Perón, H. J. M. C. (2010). Production and composition of anatomical fractions of four sorghum hybrids under nitrogen dosages. Revista Brasileira de Saúde e produção Animal, 11(3), 570-580. Recuperado de http:// revistas.ufba.br/index.php/rbspa/article/ viewArticle/1621

Perazzo, A. F., Santos, E. M., Pinho, R. M. A., Campos, F. S., Ramos, J. P. D. F., Aquino M. M. D., \& Bezerra, H. F. C. (2013). Características agronômicas e eficiência do uso da chuva em cultivares de sorgo no semiárido. Ciência Rural, 43(10), 1771-1776. doi: 10.1590/S0103-84782013001000007

Raij, B. V. (1991). Fertilidade do solo e adubação. Piracicaba: Ceres.

Rodrigues, J. A. S., Tomich, T. R., Gonçalves, L. C., Albuquerque, C. J. B., Guimaraes, A. D. S., Fernandes, L. D. O., \& Paes, J. M. V. (2014). Sorgo forrageiro para silagem, corte e pastejo. Informe Agropecuário, 35(278), 50-6. Recuperado de http://ainfo.cnptia.embrapa.br/digital/bitstream/ item/102290/1/Sorgo-forrageiro.pdf

Santos, R. D. D., Pereira, L. G. R., Neves, A. L. A., Rodrigues, J. A. S., Costa, C. T. F., \& Oliveira, G. F. D. (2013). Agronomic characteristics of forage sorghum cultivars for silage production in the lower middle San Francisco Valley. Acta Scientiarum. Animal Sciences, 35(1), 13-19. doi: 10.4025/ actascianimsci. v35i1.13072

Sher, A., Hassan, F. U., Ali, H., Hussain, M., \& Sattar, A. (2017). Enhancing forage quality through appropriate nitrogen dose, seed rate and harvest stage, in sorghum cultivars grown in Pakistan. Grassland Science, 63(1), 15-22. doi: 10.1111/grs.12137

Silva, A. L., Edvan, R. L., Bezerra, L. R., Ratke, R. F., Rodrigues, J. A. S., Amorim, D. S., \& Araújo, M. J. (2019). Chemical composition and in situ degradability of silages from dual-purpose sorghum hybrids. Semina: Ciências Agrárias, 40(4), 1565 1576. doi: 10.5433/1679-0359.2019v40n4p 1565

Silva, A. L., Edvan, R. L., Bezerra, L. R., Araújo, M. J., Costa, J. H., F ., Costa Torreão, J. N., \& Nascimento, R. R. (2020). Caracterização agronômica e composição química de híbridos de sorgo para silagem em condições de sequeiro. Semina: Ciências Agrárias, 41(2), 407-420. doi: 10.5433/1679-0359.2020v41n2p407

Silva, D. J., \& Queiroz, A. C. (2002). Análise de alimentos (métodos químicos e biológicos (3a ed.). Viçosa, MG: Universidade Federal de Viçosa.

Silva, R., Santos, A., Tabosa, J. N., Gomes, F., \& Almeida, C. (2012). Avaliação de diferentes híbridos de sorgo para forragem e silagem. Revista Brasileira de Milho e Sorgo, 11(6), 225-233. doi: 10.1590/S 1516-35982001000800020

Sousa, D. M. G., \& Lobato, E. (2004). Cerrado: correção do solo e adubação (2a ed.). Planaltina: EMBRAPA Cerrados.

Tazoe, Y., Sazuka, T., Yamaguchi, M., Saito, C., Ikeuchi, M., Kanno, K., Kojima, S., Hirano, K....Makino, A. (2016). Growth properties and biomass production in the hybrid C4 crop Sorghum bicolor. Plant Cell Physiology, 57(5), 944-952. doi: 10.1093/pcp/pcv158.

Tolentino, D. C., Rodrigues, J. Á. S., Pires, D., Veriato, F. T., Lima, L. O. B., \& Moura, M. M. A. (2016). The quality of silage of different sorghum genotypes. Acta Scientiarum. Animal Sciences, 38(2), 143-149. doi: 10.4025/actascianimsci.v38i2.29030

Tyrolová, Y., Bartoň, L., \& Loučka, R. (2017). Effects of biological and chemical additives on fermentation progress in maize silage. Czech Journal of Animal Science, 62(7), 306-312. doi: 10.17221/67/2016CJAS

Van Soest, P. J., Robertson, J. B., \& Lewis, B. A. (1991). Methods for dietary fiber, neutral detergent fiber, and nonstarch polysaccharides in relation to animal nutrition. Journal of Dairy Science, 74(10), 35833597. doi: 10.3168/jds.S0022-0302(91)78551-2

Veriato, F. T., Pires, D. A. D. A., Tolentino, D., Alves, D. D., Jayme, D. G., \& Moura, M. M. A. (2018). Fermentation characteristics and nutritive values of sorghum silages. Acta Scientiarum. Animal Sciences, 40(1), 3-8. doi: 10.4025/actascianimsci.v40i1.34458 